\title{
Insulin-dependent diabetes in a Scottish incidence and urban/rural differences
}

\author{
N R WAUGH
}

From the Department of Community Medicine, Tayside Health Board, Vernonholme, Riverside Drive, Dundee DD1 $9 N L$

SUMMARY The incidence of insulin-dependent diabetes mellitus in the 0-18 year age group was studied in Tayside Region for the years 1980 to 1983. The mean annual rate of 21.7 per 100000 is high in international terms and suggests that the rise in incidence observed in Scotland in the 1970s has continued. Urban and rural incidences were compared using postcodes. Rural rates were significantly $(0.02>p>0.01)$ higher, due mainly to the difference in rates for the $0-9$ age groups.

Variations in the frequency of a disease provoke thoughts about causes. There is a striking variation in incidence of diabetes among those countries with published rates, with a 36 -fold difference between the highest (Finland) and lowest (Japan). ${ }^{1}$ There are also variations within countries. ${ }^{2}$ An international workshop on diabetes epidemiology recently called for more studies of incidence so that the effects of geographical, racial, and temporal variables could be studied. $^{3}$

Patterson et al ${ }^{4}$ reported a steep rise in incidence of insulin-dependent diabetes in Scottish children during the period 1968-76, and this rise continued into the late seventies. ${ }^{5}$ Their method, based on hospital discharge records, slightly overestimates true incidence but is reliable for secular trends. ${ }^{6}$ The same study $^{4}$ found marked variation within Scotland in hospital admission rates for insulin-dependent diabetes, and the authors concluded that there was an inverse relationship between incidence and population density. However, it is possible that children in rural areas, living many miles from hospital clinics and sometimes some distance from their general practitioners, are more likely to be admitted, for example for insulin adjustments than children in cities with easy access to diabetic services.

The aims of the present study were to determine the incidence for Tayside for 1980-3 and to examine the apparent link with population density. Tayside (population 394 415) is a suitable area for such enquiries, being geographically discrete, having a mixture of industrial city (Dundee) and rural hinterland stretching back into Highland glens, and having a community health index, based on the population registered with general practitioners, which generates a unique patient number used for all hospital purposes, ${ }^{7}$ making record linkage much easier.

\section{Method}

To ensure as complete ascertainment as possible, several sources of data were used. The primary one was a list of all admissions to Tayside hospitals of patients aged 0 to 20 years with a diagnosis of diabetes mellitus (as either the primary or secondary diagnosis) covering the years 1972-83 (all the years for which such lists were available). This list was derived from? the Scottish Morbidity Record form completed after all discharges. ${ }^{8}$ By comparing each year with all available previous ones, the lists for 1980 to 1983 were reduced to patients with no previous admission recorded. Case notes for these patients were consulted to determine true year of onset and to exclude those not resident in Tayside. Onset was taken to be the start of insulin therapy. Any patient not starting insulin at diagnosis of diabetes was excluded. Only one patient came into this category-a 16 year old who was on a sulphonylurea for two years before starting insulin and who was therefore not classified as insulindependent.

Registers of diabetic school children, maintained by the community health services (which includes the school medical service), were checked. Other sources used included cards sent in during the changeover to 100 units/cc insulin in 1983, a five month survey of insulin prescriptions in 1984, a diabetic register for the Ninewells Hospital adult diabetic clinic based on outpatient contacts from 1983 to 1985, and a register maintained by the Ninewells Hospital paediatric clinic. 
Denominators were from the 1981 census and the Registrar General's mid-year estimates for other years based on the census. Urban/rural codes and social class distribution of enumeration districts were obtained from the General Register Office Postcode Directory. ${ }^{9}$ The urban/rural (U/R) classification is:

$U / R$ code 1 not relevant to Tayside

U/R code 2 situated in a continuous urban block of $100000-999999$ population

U/R code 3 situated in a continuous urban block of $10000-99999$ population

$U / R$ code 4 situated in a continuous urban block of 1 000-9 999 population

$U / R$ code 5 situated in a rural area or in a continuous urban block of less than 1000 population.

Comparison of urban/rural rates was done using a pooled estimate method ${ }^{10}$ to calculate standard errors.

\section{Results}

As reported elsewhere, ${ }^{6}$ use of hospital admission data alone, without validation by referral to case notes, leads to an overestimate of incidence by the inclusion of, for example, holidaymakers and children who are already diabetic coming to live in the area. No extra cases were found by checking the community health registers of diabetic school children, hospital clinic registers or the "U100" insulin conversion cards, and in this age group no extra cases were detected through the survey of insulin prescriptions. Annual and mean incidences are shown in table 1. The 1981 rate is not significantly lower. Variation is to be expected from year to year, and the chance event here is perhaps not

Table 1 Annual incidence per 100000 children aged $0-18$ yers inclusive for all Tayside

\begin{tabular}{|c|c|c|c|c|}
\hline$\frac{\text { Year }}{1980}$ & $\begin{array}{l}\text { Number } \\
28\end{array}$ & \multicolumn{3}{|c|}{ Annual incidence per $10^{5}(S E)$} \\
\hline $\begin{array}{l}1980 \\
1981 \\
1982 \\
1983 \\
1980-83\end{array}$ & $\begin{array}{l}28 \\
15 \\
25 \\
23 \\
\text { mean incidence }\end{array}$ & $\begin{array}{l}25 \cdot 7 \\
13 \cdot 9 \\
23 \cdot 8 \\
22 \cdot 4 \\
21 \cdot 7\end{array}$ & (SE 2.3) & $\begin{array}{l}(4 \cdot 9) \\
(3 \cdot 6) \\
(4 \cdot 8) \\
(4 \cdot 7)\end{array}$ \\
\hline
\end{tabular}

that 1981's rate is lower than the rest, but that the other years' rates are similar. Rates are given as means (for 1980-3) for age and sex in table 2. The male excess was not statistically significant, with $95 \%$ confidence limits of male proportion $46-66 \%$.

For urban/rural comparison, rates are for ages 0-19 inclusive, rather than the more usual 0-18 inclusive, to match age group denominators from the census. Rural rates (U/R codes 4 and 5$)$ were higher than urban (U/R codes 2 and 3 ). The male/female ratio appeared to correlate with incidence rate, but this was not statistically significant (table 3 ).

Table 4 shows incidence rates by broad age group. The rural excess is mainly among younger children.

Table 5 shows an alternative analysis of city versus town and country, ie, Dundee City versus the rest of Tayside.

The male/female proportions are slightly different with 26 males and 25 females in urban areas (UR 2 and 3) compared to 26 males and 17 females in rural areas (UR 4 and 5), but not significantly so.

Social class of patients was not recorded. A curious finding, however, was that those enumeration districts with incident cases had a significantly lower proportion of social classes I and II than enumeration districts without a new diabetic (table 6).

This did not apply to $U / R$ code 3 .

\section{Discussion}

The incidence of insulin-dependent diabetes in Tayside children is high in international terms (table 7), though there are dangers in comparing one part of one country with the whole of another. For example, the Tayside rate, though well above the all-Norway rate, is lower than rates for the southeastern counties of Norway. ${ }^{15}$

Some of the differences may be due to the time of the various studies. The increase in insulin-dependent diabetes in Scotland in recent years has already been mentioned, ${ }^{45}$ and increases have been observed in Sweden (see table 7) and Finland. ${ }^{2}$

Marked differences have been found within countries. Christau et al ${ }^{16}$ found differences within

Table 2 Mean annual incidences for 1980-3; rates per 100000 in different age and sex groups

\begin{tabular}{|c|c|c|c|c|c|c|c|c|c|}
\hline \multirow[b]{2}{*}{ Age $(y r)$} & \multicolumn{3}{|l|}{ Males } & \multicolumn{3}{|l|}{ Females } & \multicolumn{3}{|l|}{ Total } \\
\hline & Number & Rate & $(S E)$ & Number & Rate & $(S E)$ & Number & Rate & $(S E)$ \\
\hline $\begin{array}{c}0-4 \\
5-9 \\
10-14 \\
15-18\end{array}$ & $\begin{array}{r}8 \\
10 \\
17 \\
16\end{array}$ & $\begin{array}{l}17 \\
19 \cdot 7 \\
26 \cdot 7 \\
28 \cdot 7\end{array}$ & $\begin{array}{l}(6) \\
(6 \cdot 2) \\
(6 \cdot 5) \\
(7 \cdot 2)\end{array}$ & $\begin{array}{r}8 \\
10 \\
11 \\
11\end{array}$ & $\begin{array}{l}17.8 \\
20.7 \\
18 \cdot 2 \\
20.6\end{array}$ & $\begin{array}{l}(6 \cdot 3) \\
(6.5) \\
(5.5) \\
(6.2)\end{array}$ & $\begin{array}{l}16 \\
20 \\
28 \\
27\end{array}$ & $\begin{array}{l}18.2 \\
20.2 \\
22.8 \\
24.8\end{array}$ & $\begin{array}{l}(4 \cdot 5) \\
(4 \cdot 5) \\
(4 \cdot 3) \\
(4 \cdot 8)\end{array}$ \\
\hline $0-18$ & 51 & $23 \cdot 5$ & $(3 \cdot 3)$ & 40 & $19 \cdot 3$ & (3.1) & 91 & $21 \cdot 7$ & $(2 \cdot 3)$ \\
\hline
\end{tabular}

Populations based on 1981 census and Registrar General's estimates for 1980, 1982, and 1983. 
Table 3 Mean annual incidences for enumeration districts grouped by urban/rural (U/R) code; rates per 100000 for ages 0-19 inclusive, with male/female ratio

\begin{tabular}{lll}
\hline UR code & Incidence $/ 100000(S E)$ & $M / F$ ratio (cases) \\
\hline 2 & $14.7(2.7)$ & 0.9 \\
3 & $21.0(4.5)$ & 1.2 \\
4 & $33.5(7 \cdot 1)$ & 1.6 \\
5 & $29.1(6.3)$ & 1.5 \\
\hline
\end{tabular}

Table 4 Mean annual incidences by urban/rural location and age; rates per 100000 for 1980-83.

\begin{tabular}{|c|c|c|c|c|c|c|c|}
\hline \multirow{3}{*}{$\frac{\text { Age }(y r)}{0-9}$} & \multicolumn{3}{|l|}{ UR $2+3$} & \multicolumn{4}{|l|}{$U R 4+5$} \\
\hline & \multirow{2}{*}{$\begin{array}{l}\text { Number } \\
14\end{array}$} & \multicolumn{2}{|c|}{ Rate $S E$} & \multirow{2}{*}{$\begin{array}{l}\text { Number } \\
22\end{array}$} & \multicolumn{3}{|c|}{ Rate $S E$} \\
\hline & & $11 \cdot 0$ & 2.9 & & $37 \cdot 1$ & 7.9 & $0.01>p>0.001$ \\
\hline $10-19$ & 37 & $21 \cdot 3$ & 3.5 & 20 & 25.6 & 5.7 & \\
\hline $0-19$ & 51 & 16.9 & $2 \cdot 4$ & 42 & 30.5 & 4.7 & $0.02>p>0.01$ \\
\hline
\end{tabular}

Table 5 Mean annual incidences in "city" (urban/rural code 2) versus "town and country" (urban/rural codes 3, 4, and 5); rates per 100000 for $1980-83$.

\begin{tabular}{cccccl}
\hline Age (yr) & UR Code 2 & (SE) & $\begin{array}{l}\text { UR Codes } \\
3,4 \text {, and } 5\end{array}$ & (SE) \\
\hline $0-4$ & 12.8 & $(5.7)$ & 22.5 & $(6.8)$ & NS \\
$5-9$ & 7.1 & $(4 \cdot 1)$ & 30.1 & $(7.3)$ & $0.01>p>0.001$ \\
$10-14$ & 24 & $(6.6)$ & 20.5 & $(5.5)$ & NS \\
$15-19$ & 13.1 & $(4.6)$ & 32.0 & $(6.8)$ & $0.05>p>0.02$ \\
\hline
\end{tabular}

NB "Dundee City" as used here does not correspond with local authority boundaries but represents only the conurbation. The local authority boundaries enclose rural and some suburban areas with $U / R$ codes 3 to 5 .

Table 6 Social classes I and II as percentage of total population under 65 in enumeration districts (ED) with and without incident cases, for each UR code.

\begin{tabular}{llll}
\hline UR Code & $\begin{array}{l}\text { ED's with } \\
\text { incident case \% }\end{array}$ & $\begin{array}{l}\text { ED's without } \\
\text { incident case \% }\end{array}$ & \\
\hline 2 & 19.8 & 24.3 & $\mathrm{p}<0.001$ \\
3 & 23.5 & 23.4 & NS \\
4 & 22.5 & 30.6 & $\mathrm{p}<0.001$ \\
5 & 38.9 & 45.7 & $\mathrm{p}<0.001$ \\
\hline
\end{tabular}

Copenhagen County, the more affluent northern part having a lower incidence than the southern.

In Montreal, a higher incidence was observed in census tracts with higher average household incomes. ${ }^{22}$ Although an increasing gradient with latitude has been suggested, ${ }^{20}$ with incidence rates rising towards the north, within countries the reverse has been reported - the lowest rates in Norway are in the north. ${ }^{15}$ In Sweden, earlier reports suggested a higher northern rate, ${ }^{12}$ but more recent ones reveal no consistent pattern. ${ }^{13} 14$ In Finland, the east, North
Table 7 International comparisons

\begin{tabular}{lllll}
\hline Country & Years & Age range & $\begin{array}{l}\text { Incidence } \\
\text { per } 100 \text { 000 }\end{array}$ & Reference \\
\hline Finland & $1970-79$ & $0-14$ & 28.6 & 11 \\
Sweden & $1970-75$ & $0-14$ & 19.6 & 12 \\
& $1977-79$ & $0-14$ & 22.7 & 13 \\
Tayside & $1980-82$ & $0-14$ & 24.9 & 14 \\
& $1980-83$ & $0-14$ & 20.6 & \\
Norway & & $0-18$ & $21 \cdot 7$ & \\
Denmark & $1973-77$ & $0-14$ & 17.6 & 15 \\
Rhode Island & $1970-76$ & $0-14$ & $13 \cdot 7$ & 16 \\
& $1979-80$ & $0-30$ & 14 & 17 \\
Allegheny County & $1965-80$ & $0-16$ & 19 & 18,19 \\
Netherlands & $1975-80$ & $0-19$ & 11.6 & 20 \\
New Zealand & $1968-72$ & $0-16$ & 10.4 & 21 \\
Montreal & $1971-78$ & $0-17$ & 8.8 & 22 \\
Israel & $1975-80$ & $0-14$ & 3.8 & 23 \\
Japan & $1979-80$ & $0-18$ & 0.8 & 19 \\
\hline
\end{tabular}

Karelia, had the highest incidence, with a lower rate in the north. ${ }^{11}$

An inverse relationship with population density was observed in New Zealand ${ }^{21}$ and Sweden ${ }^{12}$, though not in Denmark, ${ }^{24}$ the Netherlands, ${ }^{20}$ or Norway. ${ }^{15}$ In fact $\cong$ the Oslo rate was quite high in Norwegian terms. ${ }^{15}$

In the present study the rural rate was considerablyo higher than the urban, especially in younger children. Diabetes has been suggested to resemble, in its pattern $\mathbb{\Phi} \vec{\Delta}$ of occurrence, diseases such as polio and Hodgkin's $\frac{D}{\infty}$ disease, ${ }^{25}$ the common hypothesis being delayed infection with, and hence altered response to, a virus, but the age pattern in Tayside does not appear to support this. Just which of the many environmentalo factors, differing between urban and rural areas, is (or? are) involved is not known.

A different type of delayed infection hypothesis might be suggested by the findings of Yoon et al (see reference 26 for review) that Coxsackievirus B4 becomes more diabetogenic with passage. Do children in rural areas get infected with a virus which has been rendered diabetogenic by passage through more hosts due to slower spread? Are children in more crowded cities, or parts of cities, relatively protected by faster spread, and hence less passage, of virus? The urban/ rural difference does not apply between all urban and rural areas. ${ }^{24}$ City environments vary within and among countries. The lowest Tayside rate was in the City of Dundee, which has at present considerable unemployment and areas of relative socioeconomic deprivation, half the children in the $0-19$ year age group living in post-code sectors where over $25 \%$ of households had two or more of the Scottish Development Department's indicators of relative deprivation. ${ }^{27}$ However, the incidence rate of 10.8 per 100000 (SE 3.1) in these areas was not statistically different from that of 20 (SE 4.8) per 100000 in the rest of the city. 
There have been reports that higher social classes may have higher rates of insulin-dependent diabetes ${ }^{2829}$ but uncertainty persists, ${ }^{30}$ partly because of the small size of studies and perhaps also because class is only an approximate indicator of life-style.

Insulin-dependent diabetes is clearly of multifactorial aetiology, and genetic susceptibility is important within countries but does not explain difference between countries. ${ }^{19}$

Tayside incidence for 1968-76 was not published by Patterson et al, ${ }^{4}$ but unpublished data (kindly supplied by Dr J Mann and Ms M Thorogood) shows the same general pattern, the Dundee City rate for all admissions (including readmissions) for diabetes in children 0-18 years old being lower than that for the rest of Tayside. Their data suggest that the Tayside rate was close to the Scottish average. Applying their correction method ${ }^{4}$ to the $1980-3$ Tayside data gives a rate more than double their 1968-76 mean annual incidence.

There is one area of certainty. The rise in incidence of juvenile diabetes will lead to a considerable rise in prevalence, and consequent increases in needs for diabetic, ophthalmological, renal, and other services.

I am grateful to the paediatricians, physicians, and school health doctors of Tayside for access to records, to records staff, to the Primary Care Division of Tayside Health Board, and to the Prescription Pricing Division of the Scottish Common Services Agency; to Fela Helmore and Iain Crombie for statistical advice; to Dr Gordon Patterson, of Grampian Health Board, for useful suggestions; and to Marian Sharp, of Tayside Regional Council, for supplying post-code data. Neil Drummond, of the Department of Community Medicine, University of Dundee, supplied figures on areas of deprivation; Dr Lewis Cameron made helpful criticisms of early drafts.

\section{References}

${ }^{1}$ Laporte RE, Tajima N, Akerblom H, et al. Geographic differences in the risk of insulin-dependent diabetes mellitus: the importance of registries. Diabetes Care 1985, 8 (Supp 1); 101-7.

2 Akerblom HK, Reunanen A. The epidemiology of insulindependent diabetes mellitus in Finland and in Northern Europe. Diabetes Care 1985; 8 (Supp 1); 10-16.

3 International Workshop. Recommendations on the epidemiology of insulin-dependent diabetes mellitus. Diabetes Care 1985; 8 (Supp 1); 5-9.

${ }^{4}$ Patterson CC, Thorogood M, Smith PG, Heasman MA, Clarke JA, Mann JI. Epidemiology of insulin-dependent diabetes in Scotland 1968-76: evidence of an increasing incidence. Diabetologia 1983; 24: 238-43.

5 Grisso JA, Patterson CC, Smith PG, Thorogood M, Heasman MA, Webb J. Continuing high incidence of diabetes mellitus in Scottish children. Diabetologia 1985; 28: $182-3$.

6 Waugh, NR. Incidence of diabetes in Scottish children. Diabetologia 1985; 28: 467-8.
${ }^{7}$ Angus J, Cameron L, Finlayson CF, Hopkins RT, Martin $\mathrm{KB}$, Scott JH. The Tayside Master Patient Index. Tayside Health Board, 1978.

${ }^{8}$ Heasman MA; Scottish hospital in-patient statisticssources and uses. Health Bulletin 1968; 26: 10-8:

9 Postcode Directory (User Guide 1). General Register Office for Scotland 1984.

10 Braverman JD. Fundamentals of business statistics. New York; Academic Press, 1978.

${ }^{11}$ Reunanen A, Akerblom HK, Kaar M-L. Prevalence and ten-year incidence of insulin-dependent diabetes mellitus in children and adolescents in Finland. Acta Paediatr Scand 1982; 71: 893-9.

12 Sterky G, Holmgren G, Gustavsson KH, et al. The incidence of diabetes mellitus in Swedish children 1970-75. Acta Paediatr Scand 1978; 67: 139-43.

${ }^{13}$ Dahlquist G, Gustavsson KH, Holmgren G, et al. The incidence of diabetes mellitus in Swedish children 0-14 years of age. Acta Paediatr Scand 1982; 71: 7-14.

14 Dahlquist G, Blom L, Holmgren G, Hagglof B, Wall S. Epidemiology of diabetes in Swedish children aged 0-15. Diabetologia 1984; 27: 266A.

15 Joner G, Sovik O. Incidence, age at onset and seasonal variation of diabetes mellitus in Norwegian children 1973-77. Acta Paediatr Scand 1981; 70: 329-35.

${ }^{16}$ Christau B, Kromann H, Andersen OO, et al. Incidence, seasonal and geographic patterns of juvenile onset diabetes mellitus in Denmark. Diabetologia 1977; 13: 281-4.

${ }^{17}$ Fishbein HA, Faich GA, Ellis M. Incidence and hospitalisation patterns of insulin dependent diabetes mellitus. Diab Care 1982; 5: 630-3.

18 Laporte RE, Fishbein HA, Drash HA, et al. The Pittsburgh Insulin Dependent Registry. Diabetes 1981; 30: 279-84.

19 Tajima N, Laporte R, Kitagawa T, Hibi I, Fujita H, Drash A. A comparison of the epidemiology of youth onset insulin dependent diabetes mellitus between Japan and the United States (Pennsylvania). Diabetes Care 1985; 8 (Supp 1); 100-6.

20 Vaandrager GJ, Bruining GJ, Veenhof FJ, Drayer NM. Incidence of childhood diabetes in The Netherlands: a decrease from north to south over North-Western Europe? Diabetologia 1984; 27: 203-6.

21 Crossley JR, Upsdell M. The incidence of juvenile diabetes mellitus in New Zealand. Diabetologia 1980; 18: 29-34.

22 Colle E, Siemiatycki J, West R, et al. Incidence of juvenile onset diabetes in Montreal-demonstration of ethnic differences and socio-economic class differences. $J$ Chron Dis 1981; 34: 611-6.

23 Laron Z, Karp M, Modan M. The incidence of insulindependent diabetes mellitus in Israeli children and adolescents 0-20 years of age: a retrospective study 1975-80. Diabetes Care 1985; 8 (Supp 1): 24-8.

24 Christau B, Kromann H, Christy M, Andersen OO, Nerup $\mathrm{J}$. Incidence of insulin dependent diabetes mellitus (0-29 years at onset) in Denmark. Acta Med Scand 1979; Supp 624: 54-60.

25 Hillis A. Does insulin-dependent diabetes mellitus follow the poliomyelitis pattern? Am J Epidemiol 1980;112:452A.

26 Yoon J-W, Ray UR. Perspectives on the role of viruses in insulin-dependent diabetes. Diabetes Care 1985; 8 (Supp 1): $39-44$.

27 Scottish Development Dept. Multiply deprived household tables. General Register Office for Scotland, 1982.

${ }_{28}$ Debono J, Johnson C, Betts P. Juvenile diabetes and social class. Lancet 1983 ; i: $1113-4$.

29 Tarn AC, Gorsuch AN, Spencer KM, Bottazzo GF, Lister J. Diabetes and social class. Lancet 1983; ii: 631-2.

30 Anonymous. Diabetes mellitus and socio economic factors (Editorial). Lancet 1982; ii: 530-1. 